\title{
Moral Approaches and Roles of Prophet Muhammad (S.A.W) In Empowering Persons with Special Needs
}

\section{${ }^{1}$ Md. Sirajul Islam and ${ }^{2}$ Sofiah Bt. Samsuddin}

${ }^{1}$ PhD candidate, Department of Qur'an \& Sunnah Studies, Kulliyyah of Islamic Revealed Knowledge and Human Sciences, International Islamic University Malaysia, 53100 Jalan Gombak, Selangor, Kuala Lampur, Malaysia.

${ }^{2}$ Assistant Prof. Department of Qur'an \& Sunnah Studies, Kulliyyah of Islamic Revealed Knowledge and Human Sciences, International Islamic University Malaysia, 53100 Jalan Gombak, Selangor, Kuala Lumpur, Malaysia.

Corresponding Author: Md. Sirajul Islam, PhD candidate, Department of Qur'an \& Sunnah Studies, Kulliyyah of Islamic Revealed Knowledge and Human Sciences, International Islamic University Malaysia, 53100 Jalan Gombak, Selangor, Kuala Lampur, Malaysia.

E-mail: sirajulislam1981@yahoo.com

Received date: 11 March 2018, Accepted date: 15 June 2018, Online date: 20 June 2018.

Copyright: (C) 2018 Md. Sirajul Islam. This is an open-access article distributed under the terms of the Creative Commons Attribution License, which permits unrestricted use, distribution, and reproduction in any medium, provided the original author and source are credited.

\begin{abstract}
The pre-Islamic society used to exclusion persons with special needs. The last Messenger of Allah (S.A.W) established their rights. The main aim of this study is finding His methodology in empowering this form of people. In order to achieve this objective first of all we have collected data from seven authentic sources of the Prophetic traditions; Sahih al-Bukhari, Sahih Muslim, Sunan abi Daud, Sunan ibn Mazah, Sunan Al-Tirmiji, Masnad Ahmad ibn Hambal and Sua'bul Eman. The study has found five moral approaches and twelve moral roles by analyzing collected data from the Prophetic traditions in empowering persons with special needs. These approaches and roles in dealing with them played as being the key to overcome the plight of special needs. Subsequently, these approaches and roles led to blueprint on a unique development of their life. In fact, empowering this group of people is a major challenge in the contemporary world. In view of such conditions, this study will generate a great deal of interest in this issue.
\end{abstract}

Key words: Exclusion, inclusion of disabled, moral approach, disability, special needs, Prophetic traditions.

\section{INTRODUCTION}

Persons with special needs are those people who are suffering from an illness, injury or condition that makes it difficult for them to do some work that other people do easily. Both in Muslim and non-Muslim societies all over the world people have query, curiosity and concern to know the opinion of Prophet Muhammad (s.a.w) about persons with special needs. This study is an academic effort to track down approaches and roles of Prophet Muhammad (S.A.W) in empowering special needs from authentic texts of the Prophetic traditions. In fact, Prophet's moral approaches and ethical roles are motivation and efficient guidelines in order to cope with the challenges of disabled people in each era. Therefore, His moral approaches and ethical roles in empowering persons with special needs is a significant subject of moral education.

According to Leicester, using the learning required for disability awareness to illustrate the fruitful integration of personal, professional and political moral learning also enables us to see that disability awareness is an important part of moral education (Leicester, M. 2011). The comparable term for ethics in Islam is Akhlaq, which interpreted as morality. Both philosophical and Islamic ethics face the similar set of queries; what doings are right and what doings are wrong? What morals should be pursued? How should society go about making ethical determination posed by numerous challenges (Siddiqui, A. 1997).

There is much more to be learned about the morality of disability awareness. How in mainstream society we can most effectively develop our students' understanding of, and commitment to greater justice for disabled citizens those are coping with impairment in the world (Leicester, M. 2011, Fletcher-Campbell, F. 2001). Throughout the history of humankind we see societies treated and responded to people with special needs based on their cultural belief systems (Mackelprang, R. W., \& Salsgiver, R. O., 1996). For example, the pre-Islamic Arabs used to kill their female babies for fear of possible disgrace were less hardhearted toward those afflicted with difficulties and the chronically ill (Al-Alusi, 2007, Muhammad M. Y).

Furthermore, people of Madinah used to prevent the lame and blind people from sharing food with them because they are deemed and repulsive (Al-Jadid M S, 2013). Likewise, the Spartans, with their rugged individualism, abandoned young and old people with disabilities in the countryside to die (Mackelprang, R. W., \& Salsgiver, R. O., 1996). Therefore, the divine order has been revealed to the last Messenger of Allah (S.A.W) in order to establish rights of persons with special needs by eradicating such discrimination: Allah says,

"It is no fault in the blind nor in one born lame, nor in one afflicted with illness, nor in yourselves, that ye should eat in your own houses, or those of your fathers, or your mothers, or your brothers, or your sisters, or your father's brothers or your father's sisters, or your mother's brothers, or your mother's sisters, or in houses of which the keys are in your possession, or in the house of a sincere friend of yours: there is no blame on you, whether ye eat in company or separately. But if ye enter houses, salute each other - a greeting of blessing and purity as from Allah. Thus does Allah make clear the signs to you: that ye may understand" (Al-Qur'an 24: 61).

This ayah has established inclusion of disabled people, their rights and deserved honor forever. They are a part and parcel of human resource. They can mutual cooperation, social gathering with other people in family and society. Hence, in order to empowering disabled people should enhance morality of disability awareness and fulfil their needs.

Indeed, Prophet Muhammad (S.A.W) was a master of moral education, a best role model of humanity. Almighty Allah praises about highest grade of morality, integrity, purity, sincerity, honesty, humility and righteousness of His Messenger, Allah says:

"In deed in the Messenger of Allah you have a good example to follow for him who hopes for (the meeting with) Allah and the last day, and remember Allah much" (Al-Qur'an 33:21). 
Also, Allah says:

"And you are surely on an excellent standard of character (Al-Qur'an 68:4).

Allah praises in this ayah about His Messenger's excellent standard of way of life, religious activities, character, innate disposition as well as habitual behavior (Al-Tabari, 2000, Vol. 23, P. 529-30, and Muhammad, A. 2007). Moreover, Aysha (R.A) said that "His way of life (khuluq) was the Qur'an" (Ibn Hamble, 1999, Vol. 41, P. 148, No. 24601).

Therefore, to enhance morality of disability awareness this study focuses on moral approaches and ethical roles of Prophet Muhammad (S.A.W) in dealing with persons with special needs. Hence, we can say unequivocally that if we use the moral approaches and moral roles of the last Messenger of Allah (S.A.W) in dealing with disabled people, consequently, people will show respect and sympathy to them, and societies will be aware about rights of persons with special needs without discrimination and prejudice among white-black, rich-poor, Muslims-people of other faiths. As a result, they will be able to obtain their education, job opportunity, social status, security of life in society.

Results:

The study has found by studying authentic texts of the Prophetic traditions that Prophet Muhammad (S.A.W) applied five unique moral approaches in empowering persons with special needs. First approach: Psychological improvement. Second approach: Establishing social integration. Third approach: Providing necessary legal services. Fourth approach: Teaching and Fifth approach: Employing.

Furthermore, to be successful in these unique moral approaches He played twelve significant moral roles. These roles are generally variation on the following them: (1) Honoring them as humans without discrimination. (2) Special caring as they are special needs. (3) Careful about their rights. (4) Frequently visiting them (5) Consoling and psychotherapy them with prediction about reward the paradise. (6) Patience in answering their asking and dealing with them. (7) Inspiring the mass people to be cooperative with them and careful about their rights (8) Employing them according to knowledge, proficiency and ability without discrimination. (9) Governmental caring about responsibility to persons with special needs (10) Motivating them by employing. (11) Fulfilling their legal and fair desires and (12) Praying to Allah for them.

These moral approaches and moral roles were basis of necessary all forms of caring for disability. Hence, these approaches and roles are could be applicable in all societies around the world in empowering people with special needs. However, this study inspires that further study in the Prophetic traditions may find more significant strategies in empowering persons with special needs.

\section{Discussion:}

When the world was floundering between theories that called for execution of the mentally, disabled and other theories that called for employing them in drudgery, at that situation we see Prophet Mohammad (S.A.W) was merciful to this type of people (Muhammad M.Y). This study will discuss on moral approaches of Prophet (S.A.W) in empowering person with special needs.

Prophet's Moralities in Empowering Persons with Special Needs:

Through searching in the Prophetic traditions we have found five approaches (Figure 1) in empowering person with special needs. A precisely discussion on these approaches in this study is as follow.

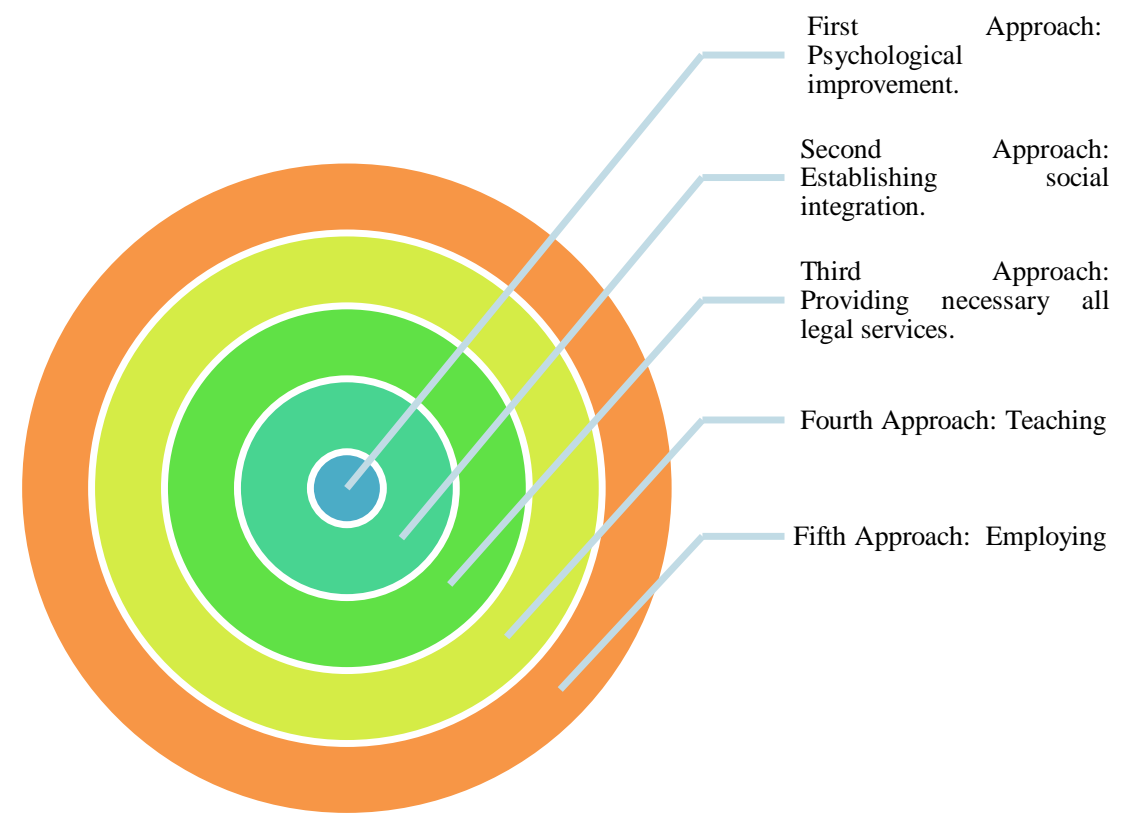

Fig. 1: Five steps in the Prophetic moralities in empowering person with special needs.

First Approach: Psychological Improvement:

Human heart is the most important organ in the body. It is also known as mind. It is very sensitive and a center of human feelings, desires, aspirations, intuitions, surmise as well as belief. Person's heart is good means he is healthy. A number of ayat 2:129, 2:151, 3:164, 24:21, and 62:2 have been revealed in the Holy Qur'an on purification of heart. For example, Allah says:

"Even as We (Allah) have sent unto you an apostle from among yourselves to convey unto you Our messages, and to cause you to grow in purity, and to teach unto you the Book and the wisdom, and to teach you that which you did not know." (Al-Qur'an 2: 151).

Therefore, Prophet Muhammad (S.A.W) was very attentive about humans' mind. He was very assiduous to purifying humans' hearts from any types of sin, disorder, depression, anxiety and so on. There are many holy sayings of Prophet Muhammad (S.A.W) in regard to heart and mind in the Prophetic traditions' text books. For instance, narrated from Numan ibn Bashir that Prophet Muhammad (S.A.W) said, "Surely, in the body there is a small piece of flesh; if it is good, the whole body is good; and if it is corrupted, the whole body is corrupted; and that is surely the heart" (Bukhari,1987, Vol. 1, P. 28, No. 52).

The medical scientists also rightly have observed the human heart. The authenticity of the holy saying of Prophet Muhammad (S.A.W) regarding heart has been proven by research of scientists in the nature of heart. Their finding is very close to the Prophet's saying about heart that mentally upset or emotional illness leads to physical illness (Vaillant, G. E. 1979, Stewart, A. J., \& Salt, P. 1981). Hence, keeping good, purity and happiness of mind is a major duty for each person. It cannot be achieved without practice a holistic life style, getting moral teaching, support, humility, forbearance, generosity and moral behave from family members and other people in society alike. 
Citation: Md. Sirajul Islam and Sofiah Bt. Samsuddin, Moral Approaches and Roles of Prophet Muhammad (S.A.W) In Empowering Persons with Special Needs. Australian Journal of Basic and Applied Sciences, 12(6): 30-35.

Usually persons with special needs are upset, disappointed, and sad and so forth for their impairment. In such situation exclusion increases their mental pain; hence, need to console and psychotherapy for reducing their sadness. Therefore, Prophet Muhammad (S.A.W) applied some major moral roles in order to improve their mentally upset or emotional illness. He taught us that everyone deserves love, care and respect. He motivated us to show compassion for all people regardless so as to people who disability, and support them by addressing their needs. Narrated from Abdullah Ibn Umar that the Messenger of Allah may Allah peace be upon him says, "God the Merciful shows mercy to merciful people, show mercy to those on earth, so that God will show mercy on you" (Abu Dawud, 2003, Vol. 2, P. 703, No. 4941).

Truly, we could be merciful by responding, appreciating, motivating, fulfilling people's rights in legal way, financial supporting according to the person's subject, issue and situation. Also, we could be kindhearted by showing sympathy as a console and a psychological support and so on through individuals and communities to heal the psychological wounds. In fact, Prophet Muhammad (S.A.W) fairly showed mercy to people in general including disability. There are three moral approaches in improving psychological aspects of disabled. These basic principles were foundation in caring psychological aspects at the beginning in order to empower them. The moral approaches are as follows:

1. Visiting the disabled people.

2. Consoling the disabled people.

3. Patience in answering the disabled people.

Visiting the Disabled People:

Visiting the sick in general and the disabled in particular had been legislated by Islam for the purpose of relieving their suffering from both mental and physical (Muhammad M.Y). Prophet Muhammad (S.A.W) used to visit the sick, pray for them and console them, instill confidence in their souls, and fulfil their hearts and faces with happiness and joy. He could once go to someone in the outskirts of Madinah particularly to answer a simple need of a person that performing salah (prayer) in the house of an afflicted one, as granting of his request (Al-Aoufi et al. 2012). An example of this was Etban Ibn Malik (R.A). He was a blind man from Ansar. He asked to the Messenger of Allah (S.A.W) "I wish that you, O Messenger of Allah, would you come and perform salah in my house so that I would take it as a place of prayer. "As a reply, the Prophet may Allah peace be upon Him, promised to visit him and perform prayer, so humbly saying, "I will do, if Allah so wills". Etban said, "Allah's Messenger and Abu Bakar came early in the morning. Allah's Messenger asked for permission to enter, which I gave". Without sitting, he immediately entered and said, "In which part of your house do you like me to pray?" I pointed to a certain place in the house, so the Messenger of Allah stood and started praying and we, in turn, stood and he lined us in a row. He performed two-rak'ah prayer, ending it with taslim (AlBukhari 1987, Vol. 1, P. 396, No. 1130). This story informs that every human being has to appreciate the disables and try to fulfil their legal desires. It is a concrete example in appreciating the disability through responding their invitation, visiting them, and fulfilling their asking.

Consoling and Psychotherapy the Persons with Special Needs:

Consoling is a generous effort to make someone who is sad, gloomy or disappointed feels better by giving them sympathy. Likewise, psychotherapy is a form of therapy frequently used to treat emotional problems and mental health conditions such as post-traumatic stress disorder (PTSD), depression, anxiety and obsessive compulsive disorder (Rewar, S. et al 2015). It is an important part of treatment for managing and working through loss of hope, anxiety, sadness, grief, and anger (Farber, et al 1999). It known as a talk therapy, it involves talking to a trained therapist either one-to-one, people in a group or with couple.

In fact, when person with special need had been suffering seriously from upset, disappoint and sadness for their disability and exclusion, at that situation the last Messenger of Allah (S.A.W) showed mercy to disabled. And his sympathy played a crucial role to improve their mental illness. Let us remember some crystal clear examples in consoling and psychotherapy to made happy the disabled people: Narrated from Ayesha (R.A) that she said: "I heard the Messenger of Allah S.A.W, said: Allah, Glorified and Exalted be He, revealed to me that whoever takes a route of seeking knowledge, the route to Paradise will be made easy for him, and that I (Allah) have been taken away from him two dear things (that's his eyes, or ears, or hands, or legs) I will reward them Paradise (Al-Bayhaki,2003, Vol. 7, P. 500, No. 5367). Indeed, each and every effort or method in order to obtain beneficial knowledge is way to the paradise.

Moreover, the Messenger of Allah (S.A.W) informs that Allah promises about persons with special needs that He will reward them paradise if they can patience on their disability (Al-Mulla, 2005). As a matter of fact, this hadith is divine condolence in removing upset of special needs. And this Hadith implicit indicates on inclusion them as they are already selected for the paradise. It means there is no any valid reason for exclusion them. Certainly, social cooperation and inclusion made them mentally happy in the Prophetic society. In addition, the Messenger of Allah (S.A.W) showed his compassion to remove their depression by informing about rewards of Allah and His forgiveness. He said: "Whoever suffers an injury and forgives the person, Allah will raise his status to a higher degree and remove one of his sins" (Muslim, 2007, Vol. 4, P. 1991, No. 2572).

Moreover, the Messenger of Allah (S.A.W) said: "Allah does not judge you according to your bodies and appearances, but He looks into your hearts and observes your deeds" (Muslim, 2007, Vol. 4, P.1986, No. 2564). These holy proverbs are playing an important role as mental therapy of person with special needs over the more than 1400 years. So, in the contemporary world we can try to improve mental illness of persons with special needs by properly applying the Prophetic approaches as consoling and psychotherapy.

Patience in Answering to Persons With Special Needs:

Giving answer to question and responding of person' asking with calm and patience is a morality. People expect this normative behavior specially person who are ill and disabled. It could be considered as a first and foremost task to make satisfied the people. The Messenger of Allah (S.A.W) used to patience in answering the needs of people including disabled. It is narrated on the authority of Anas (R.A) that a woman, somewhat mentally defected, said: "O Messenger of Allah! I have a need that I want to meet you. He responded "O mother of so and so, choose the way you like to walk in so that I may know your need and meet it". He walked with her in some route until she had her need fulfilled (Muslim, 2007, Vol. 4, P. 1812, No. 2326). This is, of course, a proof of his forbearance, humility, and patience in answering the needs of those with special needs. It also, served a legal proof that a ruler is obligated to care for people with special needs, psychologically, socially and economically. In addition, a ruler should fulfil their needs and grant their requests (Muhammad M.Y). In this hadith had been shown the moral principle of the last Prophet may Allah peace be upon Him, in answering the needs of people specially persons with special needs. It shows the Prophet's tolerance in fulfilling peoples' asking and their rights. It influences us to be awareness about peoples' needs and psychological evaluation (Al-Nawawi, 1987).

On an occasion, Allah's Messenger met a woman who complained that she suffered from epileptic fits. She expressed concern that her body would become exposed during such episodes. Prophet Muhammad offered the woman two choices. He could either pray to Allah that she could have access to paradise if she patiently resigned herself to her condition, or he could ask Allah to heal her. She opted to continue to bear her condition with patience but also asked the Prophet (S.A.W) to pray that her body might no longer become exposed to the view of strangers (Al-Bukhari, 1987, Vol. 5, P. 2140, No. 5328). This story brings out three important points. First, it illustrates the value of forbearance on the part of the persons with the disability. Second, more importantly, it affirms the right of individuals to draw attention to their special needs and to speak out for their rights as a matter of social justice. Third, the story points to the important role of advocacy and the support which the wider community is expected to provide to the individual (Hurisa Guvercin, 2013, Sheikh Isse A. Musse).

Furthermore, these are examples in social and religious responsibility. The Messenger of Allah (S.A.W) taught us that human should not deprive anybody from their deserved values and rights. Really, I firmly believe that if any person be interested and determined that he never refuse anybody with empty hand, empty mouth and empty mind, he will be successful in his desire. In another language, according to ability and situation pers on can response by giving charity gift or providing food or advising or showing condolence towards empowering persons with special needs. All these efforts are mainly mental supports for improving of psychological condition of disabled people.

\section{Second Approach: Establishing Social Integration:}

Establishing social integration in reducing interpersonal problems of persons with special needs is very essential. In order to establish rights of disabled, the Messenger of Allah (S.A.W), contributed vivid examples of the importance of social integration of disabled people with society. In one obvious example, he urged visually impaired people in the early Islamic state to participate with other people in praying in the mosque, rather than alone at home (Al-Zyoud, 2011). 
Citation: Md. Sirajul Islam and Sofiah Bt. Samsuddin, Moral Approaches and Roles of Prophet Muhammad (S.A.W) In Empowering Persons with Special Needs. Australian Journal of Basic and Applied Sciences, 12(6): 30-35.

He says: 'Verily Allah does not look at your bodies or at your faces but He looks at your hearts' (Muslim, 2007, Vol. 4, P.1986, No. 2564). On the one hand, this hadith teaches that person who disabled he should not feel shy to participate to social gathering. On the other hand, people also should not avoid them because Allah does not look at appearance of body or face of human rather He looks at people' heart. Is it pure or currapted. So, people whose hearts are pure, they are compassionate and merciful to people, they have humility, they not abhor the disabled people.

Another hadith about establishing social integration, narrated Abdullah ibn Umar (R.A) that the Messenger of Allah (S.A.W) said: 'Indeed, those people who are merciful; Allah is Merciful upon them; therefore, oh humans be merciful to those who is in the earth; He (Allah) Who is in the Heaven will be merciful to you' (Al-Tirmiji, 2009, Vol. 4, P. 323, No. 1924). This advice is to humans regardless to be merciful to people individually or collectively, to be helpful in solving their problems, to be cooperative in charity works, to be generous in eliminating communities' difficulties.

Thus, it includes persons with special needs also, and it emphasizes the people on cooperative and helpful in order to empowering those are suffering from disability. Moreover, narrated from ibn Abbas (R.A) that the Messenger of Allah (S.A.W) said: 'He is damned who punch the blinded from the path' (Ibn Hambal, 1999, Vol. 3, P. 368, No. 1875). Indeed, kindness to disable people has been mentioned in this Prophetic saying. Definitely, it is evidence on they have rights to interaction with other persons in society. They can usual walking in streets, gardens, public places. They can visit tourist places, join in mass gatherings and religious programs. Thus, this Prophetic saying plays an important role in reducing interpersonal problems of disability in societies.

Moreover, the story of Julaybib, one of the contemporaries of the Prophet, is another vivid example of establishing social integration in reducing interpersonal problems of disability. In addition to being poor, Julaybib had an unpleasant physical appearance and nobody wished to let their daughter marry him. Upon the Prophet's request, a noble family gave him their daughter in marriage. Later on, when Julaybib was martyred in a battle, the Prophet put his hand on his knee and said: "This one is of me and I am of him" (Ibn Hambal, 1999, Vol. 4, P. 421, No. 19793). This compassionate gesture of the Prophet was a powerful demonstration of the principle of inclusion. It was a tremendous act of advocacy, in word and action, on the part of a community leader to educate his people about the importance of accepting others for what they are (Hurisa Guvercin, 2013, Sheikh Isse A. Musse).

Third Approach: Social Responsibility to Provide Necessary Legal Services to Special Needs:

Providing necessary legal services unto persons with special needs is a social responsibility in Islam. Islam is a religion of love, affection and compassion. Its teachings have included all aspects of human life. It emphasizes on being attentive of social responsibility. Islam teaches man is born alone but to live with others in harmony, interaction, communication, sympathy and tranquility. Islamic ideology extends social responsibility to all of humanity, believers and disbelievers alike. It teaches to show kindness to all of mankind, irrespective of their different beliefs and ways of life, Almighty Allah says:

"O mankind! We have created you from a single (pair) of a male and a female, and made you into nations and tribes, that ye may know each other (not that ye may despise each other). Verily the most honored of you in the sight of Allah is (he who is) the most righteous of you. And Allah has full knowledge and is well acquainted (with all things) (Al-Qur'an 49:13).

These social responsibility and reciprocal cooperation have been encouraged because of the honor and dignity of every human being. Allah says:

"We have honored the sons of Adam; provided them with transport on land and sea; given them for sustenance things good and pure; and conferred on them special favors, above a great part of our creation" (Al-Qur'an 17:70).

In point of fact, the Messenger of Allah (S.A.W) is a role model for mankind who was very serious about social responsibility. He showed honor, sympathy and kindness regardless of different beliefs and ways of life. For example, he honored a funeral of a Jew. Qais ibn Sa'd reported: A funeral passed by the Messenger of Allah, peace and blessings be upon him, and he stood up. It was said to him, "It is a Jew." The Prophet said, "Was he not a soul" (Al- Bukhari, 1987, Vol. 2, P. 85, No. 1312)?

Thus Prophet Muhammad (S.A.W) taught us to be attentive about dignity, right and deserved honor of human regardless. He inspired people to be cooperative and merciful to family members, relatives, orphans, street children, needy, friends, neighbors and other all members of society regardless. He motivated to work together in order to fulfil the general needs of people especially those who are incapable of fulfilling their own needs. There are many ahadith about social responsibility, one of these is narrated from Numan ibn Bashir (R.A) that the Messenger of Allah (S.A.W) said: 'See the believers in their mutual love, mercy and empathy like a body, if the organ complained about him falter, the rest of his body to ensure a fever' (Muslim, 2007, Vol. 4, P. 1999, No. 2586).

In fact, social responsibility covers everyone by steps. It starts with the Muslim and his personal sphere of life, extends to his family, then to the society that he lives in, and finally to all the diverse societies that exist on Earth. This Prophetic saying is an advice to feel each other in love, mercy and empathy like a body. And in rest of this Hadith ('if the organ complained about him falter, the rest of his body to ensure a fever') makes clear to understand the message. So, what feels a needy, a patient, a disabled, a street children and an endangered? They feel, there are needs moral behave with them, help, compassion, treatment, healthy food, good accommodation, suitable environment, social co-operation and other necessary belongings as much as possible. Hence, according to the Prophetic advice, persons who are healthy in society and doing work in various sectors they should same feeling about persons, patients and persons with special needs in order to fulfil their needs according to ability and responsibility because they are a part and parcel of society. Thus, this Prophetic saying indicates to both technical and social aspects in cooperating with one another including disabled. Mutual love, mercy and empathy have been mentioned in this Prophetic saying. It includes necessary all types of legal services, medical treatments and so forth. Prophet Muhammad (S.A.W) encourages everybody in society to be co-operated with persons, and persons with special needs according to individual ability. For example, government by making policy in empowering, teacher by teaching, rich man by financial sponsoring, physician by medical dealing and so on. In addition, the words body, organ, and falter indicate to technical aspects. Accordingly, also this Prophetic saying emphasizes on establishing hospital and employing doctors, assistant and so on based on ability and technology in order to best treatment the patients and persons with special needs.

\section{Fourth Approach: Teaching:}

Islam greatly emphasized on education. Acquiring knowledge is an obligatory duty to every Muslim, male and female alike. The first word that had been revealed to the Messenger of Allah (S.A.W) was 'Iqra' - which means Read! Seek knowledge! Be educated. The Qur'anic word 'Iqra' suggests the concept of learning, exploring, investigating and so on. The significance of teaching and education has been emphasized repeatedly in the Qur'an. For example, about increasing knowledge (20:114), and knowledge and wisdom is a best achievement (2:269), and knowledgeable person truly fear Allah (35:28), and those have knowledge and those have not knowledge both are not equal (39:9). Knowledge has been divided into two types: first type is the knowledge of religion, and second is the knowledge that essential for progressing of community. The values of religious knowledge that believe in one Allah, belief in his angels, belief in his books, belief in his messengers, belief in the last day (the day of Judgment), and belief in good and evil fortune, and knowledge about salah, fasting, reading the Qur'an and so on. And the second type of knowledge is the knowledge required by the community which makes a person a scientist, doctor, an engineer, a lawyer, an agriculturist etc. Therefore, the Qur'an has invited man to apply their intellectual power granted to man quite a number of times in interrogative manner-do you not then apply your reason? (Afala ta 'qilun), do they not then apply their reason? (Afala ya qilun). Since the man has been granted intellectual power, he is required to use it in his life. That is why man who suspends his intellectual power and falls prey to intellectual slavery stand condemned. The Qur'an reads: “The vilest of creatures in the eyes of Allah are those deaf and dumb who do not apply their reason" (Al-Qur'an 8: 22). Mehdi Golshani mentions that around more than 750 ayat of the Qur'an refer to natural phenomena, inspires man to think, observe, ponder, and reflect (Golshani M. 2011). In fact, knowledge is the way to approach the Creator. Therefore, the Messenger of Allah (S.A.W) also said "Talab Ul Ilmu Farizatun Ala Kulli Muslim" (al-Qzwyni, Vol. 1, P. 81, No. 224). Acquiring knowledge (the Knowledge of Truth and Wisdom) is an obligatory on every Muslim. Narrated from Ayesha (R.A) that she said: "I heard the Messenger of Allah may Allah (S.A.W) said: Allah, Glorified and Exalted be He, revealed to me that whoever takes a route of seeking knowledge, the route to Paradise will be made easy for him, and that I (Allah) have been taken away from him two dear things (that's his eyes, or ears, or hands, or legs) I will reward them Paradise (Al-Bayhaki,2003, Vol. 7, P. 500, No. 5367 ).

It is obvious that in the Prophetic society persons with special needs did arrive to the highest classes through obtaining the knowledge from Prophet Muhammad (S.A.W). As a result of the Prophetic teaching, they became great scholars in different areas of knowledge such as Mufassir-interpreter of the holy Qur'an, scholar in the Prophetic traditions, jurisprudences, comparative religions, sociologies, civics, foreign laws, astronomy, oceanology, ethnomedicine and so forth. From of them most prominent are Ibn Abbas, Asim al-Ahwal, Umarw ibn Akhtab al-A'raj, Abdur Rahman al-Asm, al-A'mash and so on (Al-Qalawy). Moreover, Prophet Muhammad (S.A.W) frequently did dua-(praying) for them. For instance, he prayed for Ibn Abbas "Oh Allah! Give him depth knowledge of 
Citation: Md. Sirajul Islam and Sofiah Bt. Samsuddin, Moral Approaches and Roles of Prophet Muhammad (S.A.W) In Empowering Persons with Special Needs. Australian Journal of Basic and Applied Sciences, 12(6): 30-35.

religion and knowledge in interpreting the holy Qur'an" (Ibn Hambal, 1999, Vol. 4, P. 225, No. 2397)! These statements have proved that education rights universal. Nobody deprive a disable person from his education right. Moreover, education is a key requirement in empowering the person with special needs.

Fifth Approach: Employing:

By applying abovementioned moral approaches when among them become qualified then the Prophet (S.A.W) appointed the based on their knowledge and qualifications.

\section{Employing as a Muezzin:}

Islamic history's has a shining record of many examples of people who, while having some kind of persons with especial needs, were included and had prominent status in society. Prophet Muhammad (S.A.W) not only made them skillful by teaching but also gave them job opportunity through appointing in several important sectors in order to contribute in society as well as develop their social status. For instance, Abdullah ibn Umm Maktum, who was blind, was among the first to accept Islam. He was devoted to the Prophet (S.A.W) and extremely eager to memorize the Qur'an. When the Prophet (S.A.W) arrived in Medina, he appointed Abdullah to be one of the Muezzins (muezzin's job is calling five times for congregation prayers). Narrated from Ayesha may Allah be pleased with her that Ibn Umm Maktum was a muezzin of Allah's Messenger (S.A.W) though he was blind (Abu Daud, 2003, Vol. 1, P. 202, No. 535).

\section{Employing as a Successor:}

On several occasions, the Messenger of Allah (S.A.W) placed Abdullah Ibn Umm Maktum (R.A) in charge of Medina in his absence. "Narrated from Anas Ibn Malik (R.A) that the Messenger of Allah (S.A.W) appointed Ibn Umm Maktum twice as his successor in Madinah to lead the prayer, though he was blind (Abu Daud, 2003, Vol. 2,P. 146, No. 2931, and Ibn Hambal, 1999, Vol. 20, P. 307, No. 13000). Definitely, this is a remarkable example of inclusion that shows how people with disabilities had been looked upon and treated in Islam. What we learn from this outstanding act of our prophet is that we should not belittle disabled people or make superficial judgments because although people have certain disabilities they might be capable of doing great deeds, and it is also important to delegate leadership responsibilities to disabled people when they are capable of such duties (Hurisa Guvercin, 2013).

\section{Employing as an Ambassador:}

He is a Sahabi Muadh bin Jabal (R.A), one of the greatest scholars among Sahaba. The Prophet (S.A.W) selected him and sent to Yemen as His an ambassador, and even wrote a letter to Yemen's family: "I have sent you who is the best in my family". He was a lame; the lameness not prevents him from rightful place in the political and social life of Islam (Al-Qalawy). Also, during the high centuries of Islamic civilization a significant number of blind, deaf or physically disabled people played notable roles as physiologists, lawyer, teachers, poets, and social commentators, outstanding among whom were Abu'l Ala alMa'arri, Abu Uthman Amr bin Bahr (Al-Jahiz), Bashshar Ibn Burd, Ibn-Sirin, Qatada Ibn Di'ama al-Sadusi, Muwaffaq al-Din Muzaffar, and Thalab. Atta Ibn Abi Rabah who was black, lame and partially paralyzed, was known as the greatest Mufti in Mecca (Hurisa Guvercin, 2013).

\section{Conclusion:}

Moral education is a key requirement to be real successful in empowering persons with special needs (Fig-2). Prophet Muhammad (S.A.W) was a master of moral education, a role model of humanity. His highest grade of morality, integrity, purity, sincerity, honesty, humility and righteousness led to disability awareness which made him sympathetic to this group of people. Subsequently, sympathy to disabled people motivated him to empower them, which inspired to select some moral approaches to empower them. In addition, to be successful in selected moral approaches he played some significant moral roles. Consequently, persons with special needs issue take palce an important subject in the Prophetic traditions. Their education, respect, social status, job opportunity and so forth were available in the Prophetic society. It is a concise example of the Prophetic morals in mutual supporting, cooperating, consoling, honoring, respecting, caring and empowering persons those with special needs. In fact, there have basis of necessary all types of caring for disability in the Prophetic traditions. In addition, the Prophetic principles, and His sayings emphasized on establishing hospital and employing doctors, assistant and so on based on ability and technology. For example, on the one hand, frequently disables were coming to the Prophet Muhammad (S.A.W) and he did show his forbearance, humility, and patience in answering the needs of those with special needs. This is a foundation on disabled people and other types of patients coming to doctors. On the other hand, also Prophet Muhammad (S.A.W) used to visit the persons who disabled. This is an example in doctor also should visit the patients if they cannot go to hospitals, clinics and meets the doctors. Truly, moral education first will encourage and enable the people to realize their responsibility about disability awareness. And disability awareness will lead to take approaches for empowering the disabled people, and ethical roles will play a major role to enable specialists, physicians and people in advancing step by step in empowering persons with special needs.

Moral education will lead to

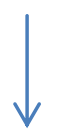

Disability awareness

$$
\downarrow
$$

Sympathetic to disabled people<smiles>CCCCCCCCCC</smiles>

Select moral approaches for empowering the disabled people

$$
\downarrow
$$

To be successful in moral approaches need to apply some moral roles.

Fig. 2: Importance of moral education in empowering persons with special needs. 
Furthermore, it is an effort to give a message the mass people that not only the government, physicians, physiologists and sociologists are responsible in empowering this category of people in society, but also civil society as well as the general public could contribute according to his/her ability and moral responsibility by following the Prophet's approaches and roles.

\section{REFERENCES}

Abu Daud, S.I.A., 2003. Sunan abi Daud, reviewed by Muhammad Muhiuddin Abdul Hamid, Dar al-Fikr publisher, 1: 202.

Al-Alusi, S.M., 2007. Ruhul Ma'nifiTafsir Qur'an al-A'zimwa al-sab' al-Masani, 14: 12.

Al-Aoufi, H., N. Al-Zyoud and N. Shahminan, 2012. Islam and the cultural conceptualization of disability, International Journal of Adolescence and Youth, 17(4): 205-219.

Al-Bayhaki, A.B., 2003.Sua'bul Eman.1 $1^{\text {st }}$ ed. Cairo.Maktabah al-Rusth publisher, 7: 500.

Al-Bukhari, M.I.I., 1422. Sahih al-Bukhari, reviewed by Muhammad Zahir ibn Nasir, $1^{\text {nd }}$ ed. Mansurah-Egypt.DaruTwaq al-Najah Publisher, 8: 10.

Al-Bukhari, M.I.I., 1987. Sahih al-Bukhari, reviewed by MustufaDaib al-Baga, $2^{\text {nd }}$ ed. Bayrut.DarulIbnkathir Publisher, 1: 164.

Al-Jadid, M.S., 2013. Disability in Saudi Arabia.Saudi medical journal, 34(5), 453-460.

Al-Mulla, A.Q., 2005. Mirqatu al-Mafatih sharhi Mashkatu al-Masabih, 2: 179.

Al-Nawawi, A.Z.Y., 1987. Sharhe Muslim, Bayrut-Lubnan. Daru al-Kitab al-Arabi publisher, 7: 86.

Al-Qalawy, M., 2014. Nazratu Islamiyytu ala dhawa al-Ihtiyajatu al-khassa, available in http://www.saaid.net/arabic/289.htm, retrieved on $29 \mathrm{March}$.

Al-Qzwyni, Muhammad IbnYazid Abu Abdullah, 2001. Sunan Ibn Majah, review: Muhammad Fuad Abdu al-Baqi, Dar al-Fikr-Bayrut.

Al-Tabari, A.J., 2000. Jamiul Bayan fi Ta bil Al-Qur'an, Review by Ahmad Muhammad Shakir, publisher: Muassasatu al-Risalah, 1st edition.

Al-Tirmiji, Muhammad ibn Iisa Abu Iisa, 2009. Al-Jaami al-Suhih Sunan al- Tirmiji, review: Ahmad Muhammad Shakir and other, Dar Ihyau al-Turaas alArabi-Bayrut.

Al-Zyoud, N., 2011. An investigation into the current service provision for students with learning difficulties in Jordan: Teachers' perspectives (Doctoral dissertation, Brunel University School of Sport and Education PhD Theses).

Farber, E.W., J.S. McDaniel, 1999. Assessment and psychotherapy practice implications of new combination antiviral therapies for HIV disease. Professional Psychology: Research and Practice, 30(2): 173.

Fletcher-Campbell, F., 2001. Editorial: inclusion, learning disabilities and moral education, Journal of Moral Education (Special Issue), 30(3): 229-234.

Golshani, M., 2011. The Holy Qur'an and the science of nature, $3^{\text {rd }}$ edn, P. 45, Kuala Lumpur-Amin research and cultural centre.

Hurisa Guvercin, 2013. People with Disabilities from an Islamic Perspective, available in: http://www.fountainmagazine.com/Issue/detail/People-with-

Disabilities-from-an-Islamic-Perspective, accessed on 06/September/ 2013.

Ibn Hambal, A.A., 1999. Masnad Ahmad ibn Hambal, review by: Suyibul Arnuth and others. $2^{\text {nd }}$ ed. Cairo.Muassasatu al-Risalah publisher, 5: 65.

Leicester, M., 2011. Triadic moral learning and disability awareness. Journal of Moral Education, 40(3): 319-327.

Mackelprang, R.W. and R.O. Salsgiver, 1996. People with disabilities and social work: Historical and contemporary issues. Social work, 41(1): 7-14.

Muhammad, A., 2007. The e-text version of the book The Message of The Quran.

Muhammad, M.Y., 2013. The Prophet's Care for People with Special Needs, Available in http://www.usislam.org/islamicyouth/ Muhammad/Prophet's\%20Care\%20for\%20People.htm, Retrieved on 5 September.

Muslim, I.H., 2007. Sahih Muslim, review by Muhammad Fu'ad Abdul Baqi. Bayrut. Daru Ahyauturas al-Arabi Publisher, $4: 1812$.

Rewar, S., D. Mirdha and P. Rewar, 2015. Post-Traumatic Stress Dis-order (PTSD): An Overview. Int J Behav Res Psychol, 3(6): 134-139.

Sheikh Isse A. Musse, 2013. Disability: an Islamic insight, available in: http://www.naseeb.com/villages/journals/article-from-australia-on-disability-andislam-5380, accessed on: 09/September.

Siddiqui, A.. 1997. Ethics in Islam: key concepts and contemporary challenges. Journal of Moral Education, 26(4): 423-431.

Stewart, A.J. and P. Salt, 1981. Life stress, life-styles, depression, and illness in adult women.Journal of Personality and Social Psychology, $40(6): 1063$.

Vaillant, G.E., 1979. Natural history of male psychologic health: Effects of mental health on physical health. New England Journal of Medicine, 301(23): $1249-1254$ 